\section{Traceability: the tobacco industry is part of the problem, not the solution}

\author{
Luk Joossens
}

Tobacco industry executives have a track record of cheating and lying, but sometimes they tell the truth. On 3 February 2000, under the banner 'Dilemma of a cigarette exporter', Kenneth Clarke wrote an opinion piece for The Guardian in his capacity as Deputy Chairman of British American Tobacco (BAT). In this piece, Kenneth Clarke admitted that the multinational company supplies cigarettes knowing they are likely to end up on the black market. Mr Clarke said: "Where any government is unwilling to act or their efforts are unsuccessful, we act, completely within the law, on the basis that our brands will be available alongside those of our competitors in the smuggled as well as the legitimate market". ${ }^{1}$ The objective of tobacco companies is more sales, both legal and illegal.

The work of Gilmore et al suggests that the tobacco industry remains involved in tobacco smuggling and tries to control systems to reduce tobacco smuggling. ${ }^{2}$ To achieve this, tobacco companies focus on track and trace systems and promote Codentify as a system to mark packs. Codentify was originally patented by Philip Morris International (PMI) in the mid-2000s following its out-of-court settlement with the EU. In 2010, PMI licensed Codentify for free to its main competitors, the other Transnational Tobacco Companies (TTCs). In 2016, Codentify was sold to a third party Inexto, but its links with PMI remained. As a tobacco industry patented technology, Codentify does not meet the requirements of Article 8.2 of the Illicit Trade Protocol (ITP) that the tracking and tracing system should be 'controlled by the Party'. The Gilmore et al article explains that a key part of the TTCs' strategy to control track and trace systems has been to use third parties to help secure widespread, highlevel support for Codentify. In 2010, the companies said "We therefore should be mindful that governments interested in 'Codentify' need to be convinced for themselves that this is a high-quality solution, which works totally under their control and their supervision, and which is supplied by a credible third party

Correspondence to Luk Joossens, Association of European Cancer Leagues, Brussels B-1030, Belgium; joossens@gmail.com technology company".3 Late in 2017, BAT would confirm this strategy: "The industry has been developing and rolling out a tracking and tracing system for a decade and since 2014 has accelerated its plans in line with requirements of the EU Tobacco Products Directive by 2019 in co-operation with a third party solution provider". ${ }^{4}$ The Gilmore et al paper suggests they intended these third parties to give the impression of independence yet exercised considerable control over them.

In March 2018, 35 parties had ratified the WHO Framework Convention on Tobacco Control (FCTC) ITP. Forty parties are needed for the entry into force and it is likely that this will happen in 2018. One of the core measures of the Protocol is a global tracking and tracing regime (Article 8). During the coming years, the establishment of tracking and tracing systems will become a major task for governments around the world. This paper highlights the pitfalls that parties must avoid if the ITP is to successfully reduce illicit.

Since the adoption of the FCTC in $2003^{56}$ and the adoption of the ITP in $20122^{7-9}$ it has never been conceived that the tobacco industry could become a partner for the implementation of a global tracking and tracing regime. ${ }^{10}$ Tobacco industry operated systems are not an option under the rules of the ITP. The tobacco industry is part of the problem, not the solution. However, much the industry tries to distance itself from Codentify, it ultimately remains an industry solution.

Parties establishing track and trace systems should therefore take into consideration at least the following three principles.

1. Investigate thoroughly possible industry connections with so-called independent third-party contractors.

During the 2012 tender for a track and trace system in Kenya, BAT did not participate in the tender, but rather used an 'independent' third company to promote Codentify. The Gilmore et al article reveals the links between those 'independent' companies and the TTCs: the business group 'Coalition against Illicit Trade', for example, has among its members several close friends of the TTCs.

2. Never accept traceability codes generated by the tobacco industry.
The marking with unique identifiers is an obligation assigned to the Party and cannot be performed by or delegated to the tobacco industry (Article 8.12 of the ITP). The self-generation of codes is central in the industry strategy to gain control of the traceability systems. Codentify, for instance, is generated by the companies at the production line. During the consultation process for the EU traceability standards, tobacco companies lobbied for the generation of markings on individual packs in accordance with International Organization for Standardization/International Electrotechnical Commission (ISO/ IEC) $15459-4^{11}$ and GS1 standards. ${ }^{12}$ Under the GS1 system, the generation of unique identifiers for individual products and packages is a task assigned to the companies. In this case, they are the tobacco companies. ${ }^{13}$ Their attempt failed, but it is likely that tobacco companies will use the reference to ISO 15459-4 again to try to be in charge of unique identifiers in other countries.

3. Protect the unique identifiers against cloning or copying.

Tobacco companies favour digital codes because they are printed at the time of manufacturing. Those codes are often visible and can easily be cloned, recycled or migrated to be used twice for illegal practices. The visible Codentify codes are an easy target for copiers. Ross et al have demonstrated the inefficiency of Codentify compared with other solutions that incorporate material-based security features. ${ }^{14}$ Unique identifiers should be secure and protected against cloning.

In line with Gilmore et al's recommendations, governments who will ratify and implement the ITP should assume that any systems based on Codentify or promoted by the TTCs' new or emerging allies (there will no doubt be more) are incompatible with the ITP.

Funding The author has not declared a specific grant for this research from any funding agency in the public, commercial or not-for-profit sectors.

Competing interests None declared.

Patient consent Not required.

Provenance and peer review Commissioned; internally peer reviewed.

(C) Article author(s) (or their employer(s) unless otherwise stated in the text of the article) 2019. All rights reserved. No commercial use is permitted unless otherwise expressly granted.

\section{Check for updates}

To cite Joossens L. Tob Control 2019;28:121-122. Published Online First 13 June 2018 


\section{(5) Linked}

- http://dx.doi.org/10.1136/tobaccocontrol-2017054191

Tob Control 2019:28:121-122.

doi:10.1136/tobaccocontrol-2018-054352

\section{REFERENCES}

1 Clarke K. Dilemma of a cigarette exporter, Guardian. $2000 \mathrm{https}: / / \mathrm{ww}$.theguardian.com/bat/article/0, 191288,00.html (accessed 15 Apr 2018).

2 Gilmore A, Gallagher A, Rowell A. The tobacco industry's elaborate attempts to control a global track and trace system and fundamentally undermine the Illicit Trade Protocol. Tobacco Control 2019;28:131-44.

3 Hill M. Digital Tax Verification (DTV) Codentify, the industry standard, 2010.

4 British American Tobacco. Executive Summary of the comments of British American Tobacco on Commission Implementing Regulation (EU) .../.... on technical standards for the establishment and operation of a traceability system for tobacco products. 2017 https://ec.europa.eu/info/law/ better-regulation/initiatives/ares-2017-4305467_en (accessed 15 Apr 2018).

5 World Health Organization. WHO Framework Convention on Tobacco Control. 2003 http://www. who.int/tobacco/framework/WHO_FCTC_english.pdf (accessed 15 Apr 2018).

6 WHO. Guidelines for implementation of Article 5.3 of the WHO Framework Convention on Tobacco Control on the protection of public health policies with respect to tobacco control from commercial and other vested interests of the tobacco industry. http://wwww.who.int/fctel guidelines/article_5_3.pdf (accessed 15 Apr 2018).

7 World Health Organization. Protocol to Eliminate Illicit Trade in Tobacco Products. 2013 http://www.who. int/fctc/protocol/illicit_trade/protocol-publication/en/ (accessed 15 Apr 2018).

8 FCTC. Industry interference in tracking and tracing of tobacco products. $2016 \mathrm{http}: / / a p p s$. who.int/fctc/ implementation/database/sites/implementation/files/ documents/resources/NV_16_04_4Mar16_en.pdf (accessed 15 Arp 2018).

9 Conference of the Parties to the WHO Framework Convention on Tobacco Control. Decision, FCTC/
COP7(6) Status of the Protocol to Eliminate Illicit Trade in Tobacco Products (ITP). http://www.who.int/fctcl cop/cop7/FCTC_COP7_6_EN.pdf?ua=1 (accessed 15 Apr 2018).

10 Joossens L, Gilmore AB. The transnational tobacco companies' strategy to promote Codentify, their inadequate tracking and tracing standard. Tob Control 2014:23:tobaccocontrol - 2012-050796.

11 WHO. ISO/IEC 15459-4 Information technologyAutomatic identification and data capture techniquesUnique identification, Part 4: Individual products and product packages. 3rd edn. Geneva:WHO, 2014.

12 European Commission. Commission Implementing Regulation (EU) .../.... on technical standards for the establishment and operation of a traceability system for tobacco products. https://ec.europa.eu/info/law/ better-regulation/initiatives/ares-2017-4305467_en (accessed 15 Apr 2018).

13 European Commission. Application of ISO/IEC 15459 to the system of tobacco traceability, Meeting of the Group of Experts on Tobacco Policy, Power Point Presentation. Brussels: European Commission. (2017).

14 Ross H, Eads M, Yates M. Why governments cannot afford Codentify to support their track and trace solutions. Tob Control 2018;27:706-8. 